\title{
The role of plantain (Plantago lanceolata) on East Coast dryland: results from three farm case studies
}

\author{
M.J. MACFARLANE ${ }^{1}$, P.D. MUIR ${ }^{1}$ and E CROFOOT ${ }^{2}$ \\ ${ }^{I}$ On-Farm Research Limited, P.O. Box 1142, Hastings, New Zealand \\ ${ }^{2}$ Castlepoint Station, RD 9, Masterton, New Zealand \\ paul@on-farm.co.nz
}

\begin{abstract}
Three on-farm sites where plantain was sown with legumes and/or perennial ryegrass were monitored for 2 years post-sowing. On two cultivated sites in Hawke's Bay, newly sown plantain/clover pastures produced $20 \%$ and $22 \%$ more dry matter, respectively, than newly sown ryegrass/clover or established pastures. On an uncultivatable site in coastal Wairarapa, aerially oversowing of plantain and clover resulted in $282 \%$ more dry matter than resident pasture on north faces. Plantain pastures had higher clover contents and lambs had faster growth rates and higher dressing-out percentages than lambs finished on traditional ryegrass/clover pastures. Plantain and a mix of annual and perennial clovers offer a promising alternative to ryegrass-based systems in dryland. As with lucerne, plantain and erect annual clovers need to be rotationally grazed to prevent damage to the crown and growing points. The success of these alternative forages in dryland farming systems will depend on farmer willingness to embrace new grazing management techniques.
\end{abstract}

Keywords: forages, plantain, arrowleaf clover, Persian clover, balansa clover, white clover, red clover oversowing, live weight gain.

\section{Introduction}

An increasing frequency and intensity of droughts in North Island East Coast hill country has led to a search for more robust farming systems. Developing more robust dryland systems is about maximising farm production during the times of the year when moisture is not limiting rather than producing more feed during dry conditions. For the East Coast, this means producing more, better quality feed, in winter and spring, so that more stock are finished before summer. This paper reports on on-farm studies with plantain and clover and their fit within farming systems for dryland East Coast. Most work has been done with plantain (Plantago lanceolata) and white clover (Trifolium repens) mixtures, with little being done with plantain and annual clover (Trifolium sp.) mixes. 'Tonic' plantain is an upright perennial herb which is becoming popular as a specialist crop or in a pasture mix. Having a shallower tap root than lucerne, chicory or red clover, it is less tolerant of drought. Plantain requires careful management (i.e., rotational grazing) to optimise production and persistence (Charlton \& Stewart 1999). It is a vigorous seeder, capable of setting 1400-1600 $\mathrm{kg} / \mathrm{ha}$ of seed when not grazed (Kelly 2011). Data on dry matter (DM) yields of plantain is limited from East Coast dryland farms. While sheep performance has been reported to be better on plantain than traditional pastures, (Judson 2008; Kemp 2012; Moorhead et al. 2002) none of this work has been carried out on commercial farms or in dryland situations.

The annual clovers arrowleaf (Trifolium versiculosum), balansa ( $T$. michelianum), Persian ( $T$. resupinatum) and gland (T. glanduliferum) clovers have been used extensively in dryland in Australia for nearly 20 years (Nichols et al. 2006) but are relatively new to New Zealand and may have promise in summer dry areas where white clover does not persist. All are aerial seeders and grow vigorously during spring. With the exception of some cultivars of Persian clover, all produce large amounts of hard seed. Whilst arrowleaf, Persian and balansa have been tested within New Zealand research institutes (Sheath et al. 1984; Hyslop et al. 2003) there has been little transition to use on farms.

\section{Methods}

Three plantain and clover swards were established in summer dry areas of Hawke's Bay (Te Aute and Te Mahunga) and the Wairarapa (Castlepoint). Dry matter yields were measured and benchmarked against conventional pastures. At two sites (Te Aute and Te Mahunga), animal performance was also measured (Macfarlane et al. 2014). At Te Mahanga and Castlepoint annual clovers were added to increase feed quality in Year 1, with red and white clovers forming the legume content of the sward in subsequent years.

At Te Aute and Castlepoint, pasture growth rate was measured by trimming areas to $6 \mathrm{~cm}$ then covering with a $0.4 \mathrm{~m}^{2}$ exclusion cage. At 4-6 week intervals, cages were cut to $6 \mathrm{~cm}$ and dried at $80^{\circ} \mathrm{C}$ for $48 \mathrm{hrs}$. At Te Mahanga, a mower was used to trim plots to 6 $\mathrm{cm}$ and the area was fenced to exclude stock. Pasture growth $(\mathrm{kg} \mathrm{DM} / \mathrm{ha} /$ day) was calculated from the amount of regrowth between cuts. At each cut, pasture composition (plantain, legume, grass, dead, and weeds) 
was determined from a single sub-sample collected from within a cage or collected adjacent to mown areas.

\section{Site 1 - Te Aute - \\ Plantain/clover on cultivatable hill country}

Three 6-7 ha farmlets were sown on a Matapiro sandy loam soil on steep but cultivatable hill country (average slope $23^{\circ}, \mathrm{pH} 5.9$ and Olsen P $30 \mathrm{mg} /$ litre), at Te Aute Station $\left(39^{\circ} 49^{\prime} \mathrm{S}, 176^{\circ} 40^{\prime} \mathrm{E}\right)$ south of Hastings. Previously in summer brassica, the area was fully cultivated and sown using a disc drill on 24 March 2012. Three seed mixes were used in which ryegrass and plantain content varied while the clover mix remained the same (Table 1$)$. Fertiliser $(125 \mathrm{~kg} /$ ha DAP) was applied at drilling and by air on the 18 June $(45 \mathrm{~kg} / \mathrm{ha} \mathrm{N}$ ) and the 12 August (200 kg DAP $13 \mathrm{~S})$. Each paddock was rotationally grazed. Pasture growth rates were measured using five exclusion cages on similar slope and aspect.

Animal production was measured between 18 July and 1 October 2012 when a lamb grazing trial was run (Macfarlane et al. 2014). Lambs (average liveweight of $33.4 \mathrm{~kg}$ ) were allocated to farmlets. To control pasture growth, additional lambs and subsequently yearling bulls were added.

\section{Site 2 - Te Mahanga -}

\section{Plantain and clovers on flat land}

A 38.2 ha block of flat land at Te Mahanga Station $\left(39^{\circ} 46^{\prime} \mathrm{S}, 176^{\circ} 45^{\prime} \mathrm{E}\right)$ south of Hastings was fully cultivated after being in annual ryegrass and sown on 19 April 2013. The soil type was a Waipukurau sandy loam with an impervious subsoil pan resulting in the block being winter wet, with a $\mathrm{pH}$ ranging 5.1-5.5. Prior to sowing, agricultural lime was applied at $5 \mathrm{t} / \mathrm{ha}$ and $150 \mathrm{~kg} / \mathrm{ha}$ DAP was applied at sowing. The seed mix was 'Tonic' plantain $(6 \mathrm{~kg} / \mathrm{ha})$ plus $12 \mathrm{~kg}$ of clover seed: $3 \mathrm{~kg} / \mathrm{ha}$ of 'Bolta' balansa, $3 \mathrm{~kg} / \mathrm{ha}$ of 'Lightning' Persian, $3 \mathrm{~kg} / \mathrm{ha}$ of 'Tuscan' red, $1.5 \mathrm{~kg} / \mathrm{ha}$ of 'Nomad' white and $1.5 \mathrm{~kg} / \mathrm{ha}$ of 'Tribute' white clover. Balansa and Persian clovers were chosen as they had previously been outstanding performers in an annual clover

Table 1 Sowing rates $(\mathrm{kg} / \mathrm{ha})$ for three farmlets at Te Aute

\begin{tabular}{lccc}
\hline Farmlet & $\begin{array}{c}\text { Ryegrass/ } \\
\text { clover }\end{array}$ & $\begin{array}{c}\text { Plantain/ } \\
\text { ryegrass/ } \\
\text { clover }\end{array}$ & $\begin{array}{c}\text { Plantain/ } \\
\text { clover }\end{array}$ \\
\hline Ryegrass - Extreme AR37 & 20 & 20 & \\
White Clover - Nomad & 2 & 2 & 2 \\
White Clover - Tribute & 1 & 1 & 1 \\
Red Clover - Tuscan & 2 & 2 & 2 \\
Sub Clover - Denmark & 6 & 6 & 6 \\
Plantain - Tonic & & 2 & 6 \\
\hline
\end{tabular}

demonstration at this site. Nitrogen fertiliser $(40 \mathrm{~kg} \mathrm{~N})$ was applied in July 2014. The block was subdivided into 16 paddocks of near equal sizes. Pasture production was measured on improved pastures at a site $1.5 \mathrm{~km}$ away on similar soils but not subject to winter waterlogging.

The first grazing occurred on in August 2013 and subsequent grazings were carried out by trade lambs between late winter and late summer and by weaner calves from mid summer to late autumn. Animal performance measurements commenced with two mobs of 432 and 533 winter finishing lambs being rotated around the 16 paddocks. As feed on offer increased, additional lambs were added. Grazing management was to graze plantain when $15-25 \mathrm{~cm}$ high and remove lambs at a residual of $7-10 \mathrm{~cm}$. Mobs were often moved daily. During wet underfoot conditions, paddocks were skipped until they dried out. Indicator lambs (ca. $30 \mathrm{~kg}$ ) were weighed and tagged within each mob and replaced with new weighed, tagged lambs as the indicator lambs were slaughtered (ca. $40 \mathrm{~kg}$ ).

\section{Site 3 - Castlepoint -}

Plantain and clovers on un-cultivatable hill country The trial area was a 10.6 ha paddock containing a wide range of aspects and slope. The soils are derived from mudstone and are intergrades between yellow-grey and yellow-brown earths (Taihape steepland and Atua silt loam on flatter areas). Soils had an average $\mathrm{pH}$ 5.7 and an Olsen P $15 \mathrm{mg} /$ litre. Located at Castlepoint Station in coastal Wairarapa $\left(40^{\circ} 55^{\prime} \mathrm{S}, 176^{\circ} 10^{\prime} \mathrm{E}\right)$, the trial area had an average annual rainfall is $1026 \mathrm{~mm}$, falling mainly over the late autumn and winter, with occasional summer rain events. Very regular and high wind run occurs during spring and early summer which constrains pasture growth (A. Crofoot pers. comm.).

The trial area was a 10.6 ha paddock with a resident pasture of crested dogstail (Cynosurus cristatus) and danthonia (Danthonia sp.) on slopes and ryegrass (Lolium perenne) and white clover (Trifolium repens) on flatter, moister land. The area was sprayed on 22 November 2012, with glyphosate (1.64 kg a.i./ha) and tribenuron-methyl (30 g a.i./ha) and left as summer fallow. The area was re-sprayed with glyphosate (1.325 $\mathrm{kg}$ a.i./ha) and tribenuron-methyl (30 g a.i./ha). Fertiliser $(250 \mathrm{~kg} /$ ha Cropzeal $16 \mathrm{~N})$ was applied aerially on 3 April and the following day, seed was oversown by helicopter. The seed mix was 'Tonic' plantain $(5 \mathrm{~kg} / \mathrm{ha})$ and a mix of clovers: 'Arrotas' arrowleaf ( $7 \mathrm{~kg} / \mathrm{ha})$; 'Bolta' balansa (3.5 kg/ha); 'Enrich' Persian $3.5 \mathrm{~kg} / \mathrm{ha}$ ); 'Sensation' red clover ( $3 \mathrm{~kg} / \mathrm{ha})$; and 'Nomad' white clover $(2 \mathrm{~kg} / \mathrm{ha})$. Immediately after sowing, 2100 hoggets were moved around the block to facilitate treading and seed/soil contact. In autumn, the percentage of bare ground was visually estimated and the number of old established plantain plants and clover and plantain seedlings counted 


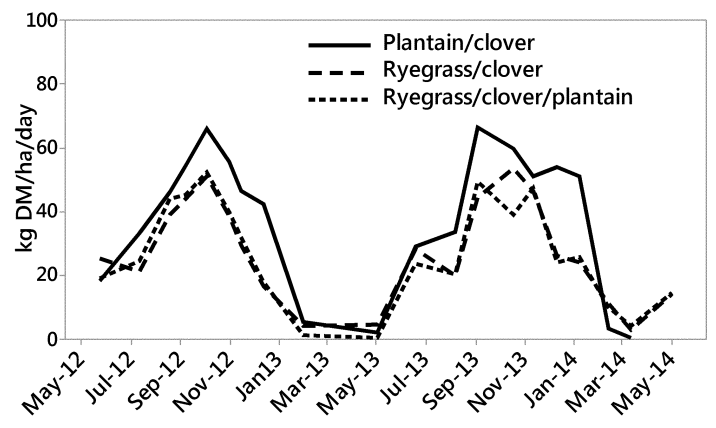

Figure 1 Te Aute - Monthly growth rate (kg DM/ha/day) for each farmlet (plantain/clover, ryegrass/clover and ryegrass/plantain/clover).

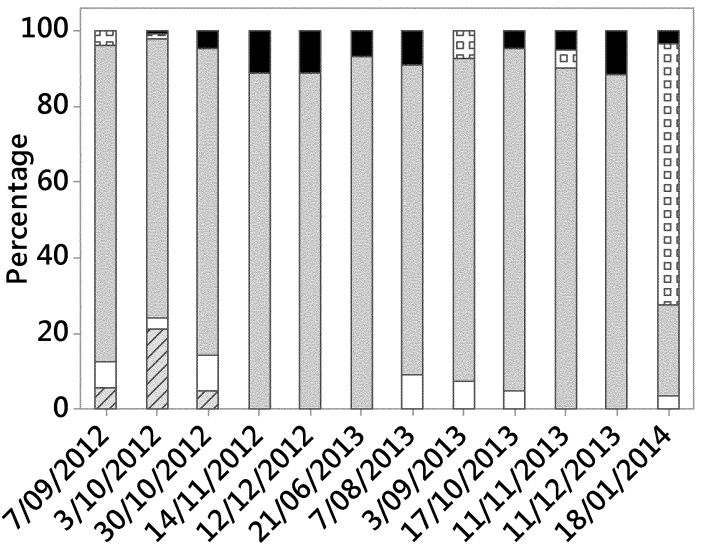

Figure 2 Te Aute - Sward composition for the ryegrass/plantain/clover farmlet at sampling dates.

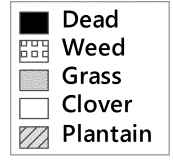

in one hundred $0.125 \mathrm{~m}^{2}$ quadrats along an established transect. The first grazing occurred on 28 June 2013 with 800 hoggets and subsequent grazings with a range of sheep classes occurred approximately monthly. While growth rates were measured using exclusion cages across a range of topography, this paper reports the growth on northern facing slopes only (average $24.5^{\circ}$ ). The growth rate of old pasture, mostly crested dogstail, danthonia and rat's tail (Sporobolus africanus), was also measured using five exclusion cages in an area of similar contour and aspect. A long term (2006-2011) pasture growth rate was also available for a similar site on the property (Clarke-Hill \& Fraser 2007). The old pasture was set stocked during lambing and then rotationally grazed with either sheep or young cattle as required. No animal measurements were recorded.

\section{Results}

\section{Te Aute}

Plantain/clover generally produced more dry matter per hectare per day than either ryegrass/plantain or

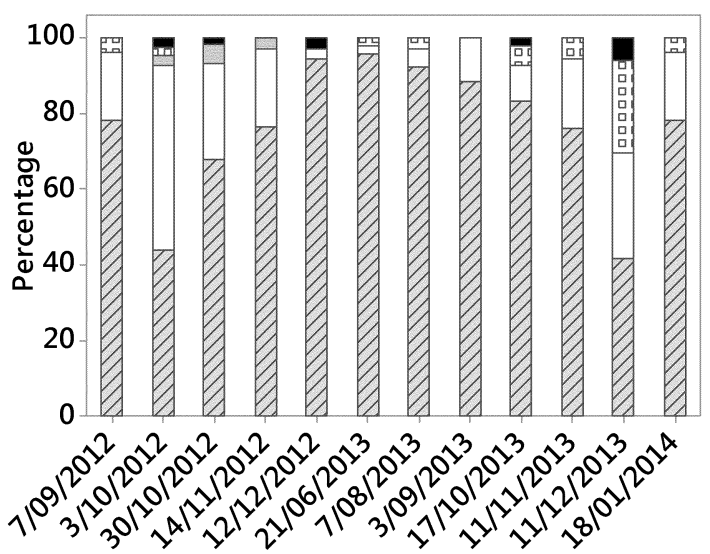

Figure 3 Te Aute - Sward composition for the plantain/clover farmlet for a range of sampling dates.
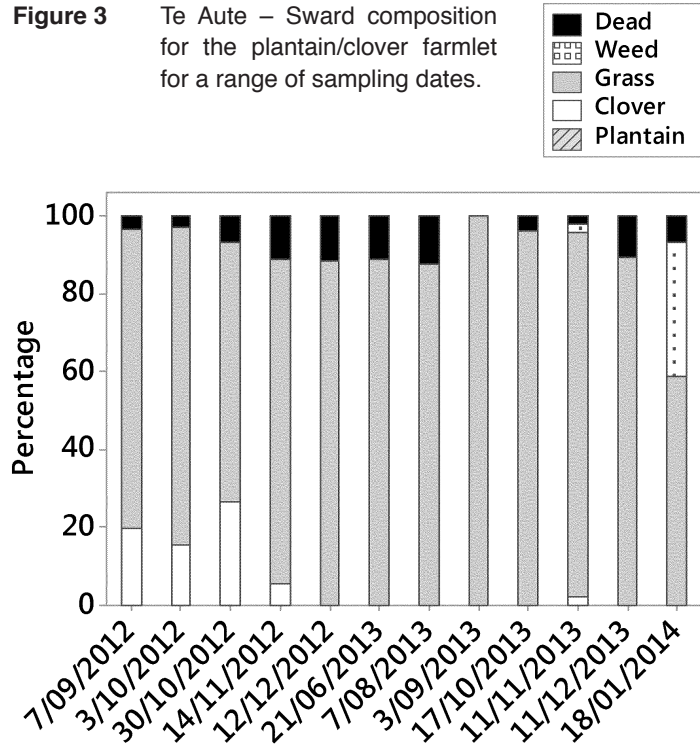

Figure 4 Te Aute - Sward composition for the ryegrass/clover farmlet at sampling dates.

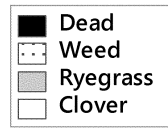

ryegrass/clover (Figure 1). Plantain/clover pasture consistently had a lower dry matter percentage (ca. $14 \%$ ) than the ryegrass-based pastures (ca. $20 \%$ ). For the 2-year period, the plantain/clover produced $4102 \mathrm{~kg}$ $\mathrm{DM} /$ ha more while the plantain/ryegrass/clover sward produced $450 \mathrm{~kg} \mathrm{DM} / \mathrm{ha}$ less, compared to the ryegrass/ clover (17 $906 \mathrm{~kg} \mathrm{DM} / \mathrm{ha})$.

Despite being sown with the same amount of clover, the plantain/clover pasture had more clover through spring $(31 \%$ on a DM basis); the ryegrass/clover pastures had $9 \%$ clover and the ryegrass/plantain/clover had $4 \%$ clover in year 1 . These declined to $8 \%, 3 \%$ and $1 \%$, respectively, in year 2 (Figures $2-4$ ). In year 1 , plantain comprised $63 \%$ of plantain/clover sward and $87 \%$ in year two. While plantain contributed $9 \%$ of the ryegrass/plantain/clover in the first spring, this 
dropped to $<1 \%$ by the second year. This suggests the $20 \mathrm{~kg}$ ryegrass sowing rate reduced the growth of both the clover and plantain as the ryegrass dominated, and there was little or no bare ground

Whilst stocking rates were similar at Te Aute, the extra dry matter enabled higher feed intakes and better liveweight gains (LWG). At the end of the 75-day grazing trial, the combination of higher liveweight gain and higher dressing out percentage $(+2 \%)$ meant that lambs on plantain/clover produced $222 \mathrm{~kg}$ of carcass weight/ha compared to $181 \mathrm{~kg} / \mathrm{ha}$ for lambs on ryegrass/ clover and $156 \mathrm{~kg} / \mathrm{ha}$ for lambs on ryegrass/plantain/ clover. Lamb growth rates were: ryegrass/clover (233 $\mathrm{g} /$ day); ryegrass/plantain/clover (205 g/day); and plantain/clover ( $273 \mathrm{~g} /$ day). At $\$ 5.50$ per $\mathrm{kg}$ carcass, this resulted an advantage of \$291/ha for plantain/ clover pastures over the ryegrass based farmlets over the 75-day grazing period. A Farmax analysis for the 12 months after sowing showed a \$357/ha advantage of plantain/clover over ryegrass clover (Table 2; Tither unpublished data). After 2 years, plantain pastures collapsed, presumably a result of uncontrolled insect damage. As the area was not being effectively monitored at the time, the actual cause remains unknown.

\section{Te Mahanga}

In year 1 , the plantain/clover sward produced $20 \%$ more dry matter more than nearby improved pastures (14 $225 \mathrm{vs.} 11888 \mathrm{~kg} \mathrm{DM} / \mathrm{ha}$ ) and $13 \%$ in year $2(12$ 874 vs. $11350 \mathrm{~kg} \mathrm{DM} / \mathrm{ha}$ ) (Figure 5). In year 1, the average legume content was $38 \%$ between August and December, with annual legumes being the major contributors. In the following year, legume content fell to $7.5 \%$ when only white clover and red clover were present. While heavy reseeding of annual clovers occurred (Macfarlane 2015) there was no obvious germination in the following autumn. The number of plantain plants has remained high, with plantain density being was 149 and 241 plants $/ \mathrm{m}^{2}$ in autumn 2014 and 2015, respectively, with of recruitment from seedlings contributing to the increasing density of plants. Higher proportions of dead material occurred during the summer, mainly due the emergence of annual grasses (barley grass (Critesion murinum) and Poa annua) (Figure 6).

\section{Table 2 Estimated gross margins}

\begin{tabular}{llcc}
\hline Site & Treatment & cents/kg DM & \$/ha \\
\hline Te Aute & Plantain/clover & 45.7 & $\$ 1774$ \\
& Plantain/ryegrass/clover & 39.9 & $\$ 1327$ \\
& Ryegrass/clover & 42.2 & $\$ 1417$ \\
Te Mahanga & Plantain/clover & 29.2 & $\$ 2785$ \\
\hline
\end{tabular}

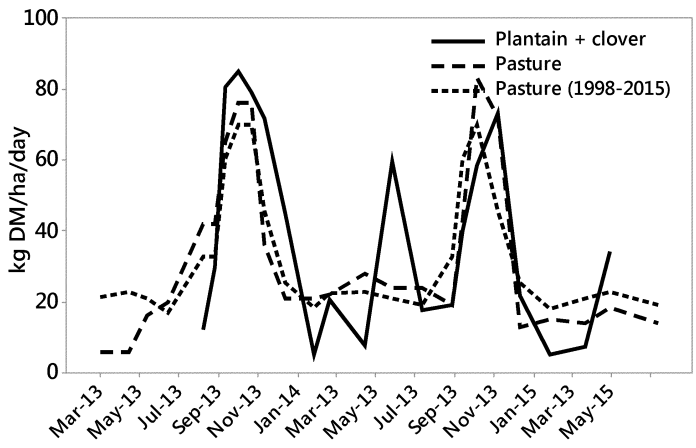

Figure 5 Te Mahanga - Monthly growth rate (kg DM/ha/ day) of plantain/clover pasture and nearby pasture and the long term mean pasture growth rate at nearby Poukawa Research Station.

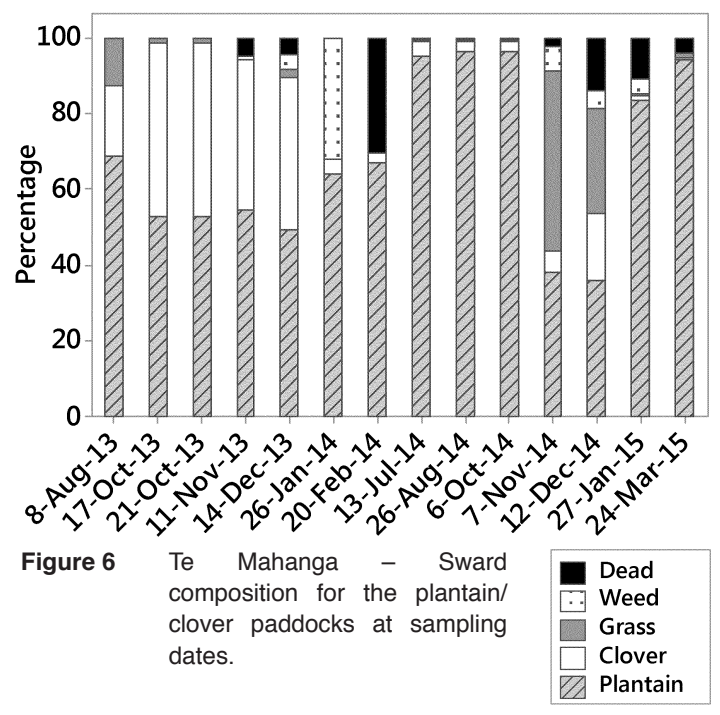

The stocking rate averaged 19.2 lambs per hectare between August 2013 and September 2014. Between 8 August and 11 November 2013, 4716 lambs were finished on the block, representing 79880 lamb grazing days. Lamb growth rates averaged $298 \mathrm{~g}$ /day and resulted in $613 \mathrm{~kg}$ of lamb liveweight gain/ha. Carcass dressing-out percentages were consistently $2 \%$ higher than other lambs finished on annual ryegrass ('Moata') on the property. A Farmax analysis indicated that at $\$ 5.50 / \mathrm{kg}$ carcass weight, these swards generated an increase in carcass value of $\$ 1633 /$ ha over pasture (Tither unpublished data).

\section{Castlepoint}

Over a 2-year period, the oversown sward produced considerably more DM across all land classes (Table 2). Northern inter-track slopes produced $282 \%$ more dry matter than existing pasture (21 915 vs. $7630 \mathrm{~kg}$ $\mathrm{DM} / \mathrm{ha}$ ). Average growth rates were $53.9 \mathrm{~kg} \mathrm{DM} /$ ha/day between 1 August to 11 December in year 1 


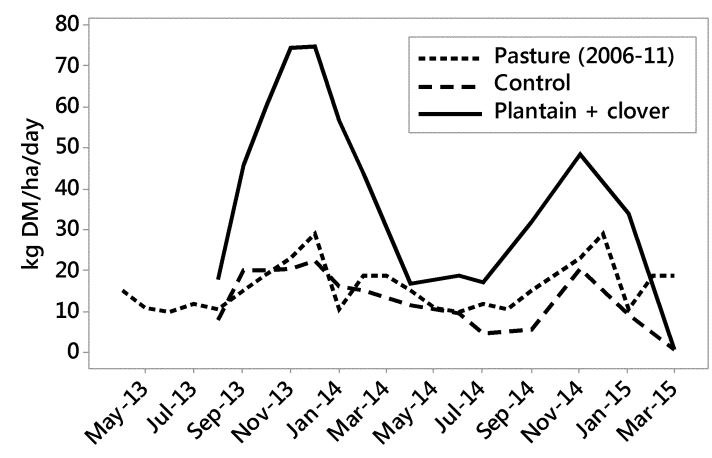

Figure 7 Castlepoint - Monthly growth rate (kg DM/ha/day) for plantain/clover on uncultivatable north facing slopes compared to a control of existing vegetation on similar slopes and a previously measured long term mean at Castlepoint Station.
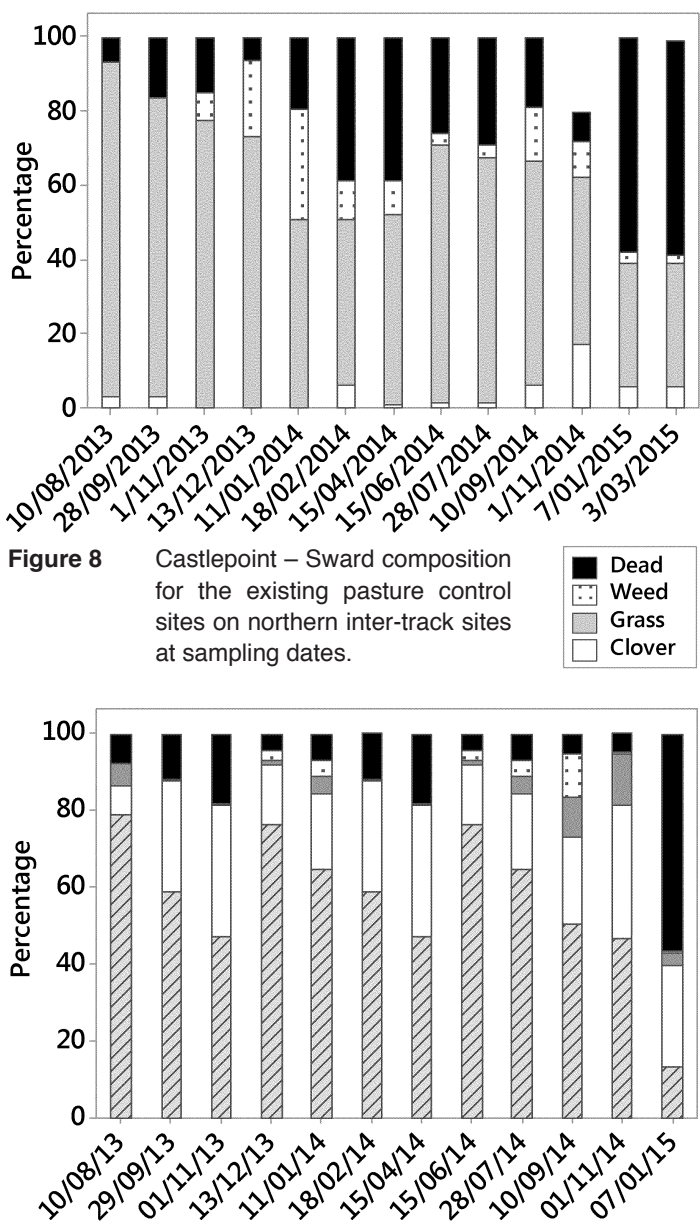

Figure 9 Castlepoint - Sward composition for the oversown plantain/clover on northern inter-track sites at sampling dates and $34.8 \mathrm{~kg} \mathrm{DM} / \mathrm{ha} /$ day in year 2 (Figure 7). In year 1 , clover content was $15.5 \%$ in August, mostly from Persian and balansa clovers and $30.9 \%$ in December, mostly from red and arrowleaf clovers (Figure 8). By comparison, control pastures grew at $19.1 \mathrm{~kg} \mathrm{DM} / \mathrm{ha} /$ day over the same period and had less than $1 \%$ clover in August and December (Figure 9). In year 2, clover content in the oversown sward was $22.5 \%$ in August and $34.4 \%$ in December, being predominately red and white clovers. The amount of bare ground increased in autumn 2014 and 2015 compared to 2013 (Table 3), largely as a result of the continued breakdown of the dead thatch. Following a 3-month summer drought in 2015 , re-establishment both plantain and clover seed was evident, with populations of establishing clovers and plantain being similar to that at initial over-sowing (Table 4).

\section{Discussion}

Winter and spring production is critical in summer dry environments. Plantain/clover produced benefits in pasture quality and quantity during this period, producing effective liveweight gains. Large advantages in dry matter production can be achieved when plantain/clover is introduced into underdeveloped lands. Higher dressing out percentages from plantain provides an additional bonus whereby effective liveweight gains are even higher than on ryegrass based pastures.

As plantain based pastures had high clover contents in spring, it appears that clovers are more compatible

Table 3 Annual DM production for each land class (kg DM/ ha/year)

\begin{tabular}{lcc}
\hline & $\mathbf{2 0 1 3}$ & $\mathbf{2 0 1 4}$ \\
\hline Ridge tops & 16113 & 8102 \\
Lower flats & 17146 & 7924 \\
Northern inter-track & 13845 & 8070 \\
Eastern inter-track & 13894 & 7369 \\
Southern inter-track & 9959 & 7310 \\
Control (northern inter-track) & 5005 & 2625 \\
\hline
\end{tabular}

Table 4

Plant and seedling number for northern inter-track

\begin{tabular}{lccc}
\hline & $\begin{array}{c}\text { May } \\
\mathbf{2 0 1 3}\end{array}$ & $\begin{array}{c}\text { May } \\
\mathbf{2 0 1 4}\end{array}$ & $\begin{array}{c}\text { May } \\
\mathbf{2 0 1 5}\end{array}$ \\
\hline Established ${ }^{1}$ plantain seedlings $/ \mathrm{m}^{2}$ & 128.8 & 173.9 & 132.5 \\
Plantain plants $/ \mathrm{m}^{2}$ & $\mathrm{NA}$ & 26.4 & 0 \\
Clover seedlings $/ \mathrm{m}^{2}$ & 62.8 & 4.6 & 34.8 \\
Bare ground \% & 14.4 & 18.5 & 21.0 \\
\hline
\end{tabular}

${ }^{1}$ new plants with two or more true leaves 
with plantain than ryegrass, possibly because of 'Tonic' plantain's reduced root competition and more open nature allows clovers to grow into the spaces between the upright plantain leaves.

Plantain is a vigorous seeder but it is essential that sites are managed to encourage seedling recruitment in autumn and early winter, particularly following severe dry periods by ensuring bare ground is present and enabling new plants to become established before grazing. While high quantities of seed can be set by arrowleaf, Persian and balansa clovers, none have yet to produce reliable regeneration in subsequent years (Macfarlane et al. 2015). A management solution that provides reliable year after year regeneration for these hard-seeded annual clovers has yet to be developed for North Island dryland. In the interim, the inclusion of annual clovers, along with suitable perennial clovers, will provide plantain with a large boost in legume content in the first spring/summer only, with perennial clovers providing the legume component in subsequent years.

Plantain/clover presents an opportunity to increase productivity of summer dry North Island hill country. Nevertheless, the loss of plantain pasture at Te Aute after 2 years indicates that management and monitoring will be a critical part of incorporating plantain into dryland farming systems.

\section{ACKNOWLEDGEMENTS}

The authors gratefully acknowledge the assistance of Guy Hamilton and Cameron Lane of Brownrigg Agriculture and Tom Bush of Castlepoint Station, Noel Smith and Kay Ward for willing measurements and Peter Swinburn and members of the Beef + Lamb Farmer Council for their oversight and direction of the project. This work was funded by MPI's Sustainable Farming Fund (Grant 11/104), Beef + Lamb NZ and the Hawke's Bay Regional Council.

\section{REFERENCES}

Charlton, J.F.L.; Stewart, A.V. 1999. Pasture species and cultivars in New Zealand - a list. Proceedings of the New Zealand Grassland Association 61: 147166.

Clarke-Hill, W.J.; Fraser, T.J. 2007. PasturePlan ${ }^{\mathrm{TM}}$ : Onfarm pasture growth and quality data for sheep and beef farms throughout New Zealand. Proceedings of the New Zealand Grassland Association 69: 73-77
Hyslop, M.G.; Slay, M.W.A.; Moffat, C.A. 2003. Dry matter accumulation and sheep grazing preference of six winter active annual legumes. Legumes for dryland. Grassland Research and Practice Series 11: 117-122.

Judson, H.G. 2008. Preliminary evaluation of plantain (Plantago lanceolata cv. Tonic) as a feed for ewe lactation. In: Proceedings of the 23rd Annual Conference of Grassland Society NSW: 130-131.

Kelly, M.J. 2011. Plantain seed production in New Zealand - Lessons in development of a new crop. International Herbage Seed Group newsletter. Number 46 December 2011 ISSN 1038-3549

Kemp, P. 2012. Plantain: what do we know? Beef + Lamb New Zealand. www.beeflambnz.com accessed 2 February 2015

Macfarlane, M.J.; Thomson, B.C.; Crofoot, E.; Hamilton, G.; Ashby, H.; Muir, P.D. 2014. Evaluating new forage systems for East Coast dryland. Proceedings of the New Zealand Society of Animal Production 74: 5-10.

Macfarlane, M.J.; Crofoot, E.W.; Muir, P.D. 2015. Effects of closing date on seeding and hardseededness of balansa, gland, Persian and arrowleaf clovers on East Coast dryland. Proceedings of the New Zealand Grassland Association 76: 219-226

Moorhead, A.J.E.; Judson H.G.; Stewart, A.V. 2002. Liveweight gain of lambs grazing 'Ceres Tonic' plantain (Plantago lanceolata) or perennial ryegrass (Lolium perenne). Proceedings of the New Zealand Society of Animal Production 62: 171-173.

Nichols, P.G.H.; Loi, A.; Ewing, M.A.; Revell, C.K.; Howieson, J.; Barbetti, M.J.; Nutt, B.J.; Snowball, R.; You, M.P.; Carr, S.J.; Foster, K.; Skinner, P.; McClements, D.; Gajda, K.; Wintle, B.; Kidd, D.; Craig, A.D.; Nair, R.; Howie, J.; Hughes, S.; Auricht, G.; de Koning, C.M.; Dear, B.S.; Sandral, G.A.; Hackney, B.; Crocker, G.; Evans, P.M.; Lloyd, D.L.; Hall, E.; 2006. Annual pasture legume improvement in southern Australia - 15 years of revolution. In: Proceedings of the 13th Australian Agronomy Conference, The Australian Society of Agronomy, Perth, Western Australia, September 10-14

Sheath, G.W.; Macfarlane, M.J.; Bonish, P.M. 1984. Evaluation of arrowleaf clover (Trifolium vesiculosum) in North Island hill country: nodulation and reseeding. New Zealand Journal of Experimental Agriculture 12: 209-217 